\title{
Interaction between the Republic of Uzbekistan and the Russian Federation in the field of science and education in the context of the innovative culture formation
}

\author{
Interacción entre la República de Uzbekistán y la Federación Rusa en el campo de la ciencia \\ y la educación en el contexto de la formación de una cultura innovadora
}

\author{
MAKHMUTKHODJAEVA Luiza S. ${ }^{1}$ \\ TALIPOVA Nigora T. ${ }^{2}$ \\ ISOXOJAEVA Munira Y. ${ }^{3}$
}

\begin{abstract}
The article presents a theoretical conceptual synthesis of scientific research in the cultural and humanitarian sphere on the example of cooperation in science and education of the Republic of Uzbekistan and the Russian Federation. The authors analyzed the trends, approaches and guidelines and used quantitative and qualitative methods of analysis and personal observations. The study found that the dynamics of growing ties in the field of education are largely similar to those of interstate relations as a whole.

Key words: innovative culture, management, higher education, science.

Resumen

El artículo presenta una síntesis conceptual teórica de la investigación científica en el ámbito cultural y humanitario sobre el ejemplo de cooperación en ciencia y educación de la República de Uzbekistán y la Federación Rusa. Los autores analizaron las tendencias, enfoques y pautas donde utilizaron métodos de análisis cuantitativos, cualitativos y observaciones personales. El estudio encontró que la dinámica de los lazos crecientes en el campo de la educación es muy similar a la de las relaciones interestatales en su conjunto.

Palabras clave: cultura innovadora, gestión, educación superior, ciencia.
\end{abstract}

\section{Introduction}

High level of interaction and sustainable indicators of economic, cultural and scientific cooperation are perhaps the main objectives in bilateral relations between the countries. Uzbekistan and Russia have already achieved many objectives of bilateral cooperation and continue successful partnership in various spheres [Talipova, 2015]. One of the priority areas of Russian-Uzbek cooperation is cooperation in science and education, which is an important component of the entire complex of Russian-Uzbek relations. The urgency of this issue is related to

\footnotetext{
${ }^{1} \mathrm{PhD}$, associated professor, head of the Department «Humanitarian and Mathematical Disciplines». Russian Economic University named after G.V.Plekhanov in Tashkent, Uzbekistan. E-mail: food-system@yandex.ru

$2 \mathrm{PhD}$, associated professor of the «International Economics» Department. Russian Economic University named after G.V.Plekhanov in Tashkent, Uzbekistan. E-mail: nigoratal@gmail.com

${ }^{3} \mathrm{PhD}$, associated professor of the «Economic Theory» Department. Russian Economic University named after G.V.Plekhanov in Tashkent, Uzbekistan. Email: munira.isokhuzhaeva@mail.ru
} 
the marked intensification of partnership between Uzbekistan and Russia in 2017-2019 and the need to summarize its first results in the field of education and science.

Let us highlight the following factors that unite both countries at the current stage of development and allow to demonstrate the relevance of the study:

- Security problems in the Central Asian region related to the penetration of extremism and the increase in drug trafficking from the south, an important role in this matter has an important role in coordinating joint measures to counteract terrorism, extremism, especially radicalization among young people.

- Economic proximity and complementarity. Both countries face similar economic problems: in particular, in Russia inflation rose by about 4.3\% in 2018 [Russian Ministry of Economic Development, 2018] and in Uzbekistan by $8.1 \%$ over the same period [State Committee on Statistics of the Republic of Uzbekistan, 2018]. National economies are closely interconnected and complementary, as evidenced by the consistently high level of trade. Uzbekistan is the fourth largest CIS member in terms of trade with Russia. At present, Russian investments in Uzbekistan's economy exceed \$8.5 billion (Fig. 1) [www.izvestia.uz, 2017].

- Mobility of the population. Russians (over 1.2 million people) and other Slavic peoples are one of the largest ethnic groups in Uzbekistan, with a population of over 33 million. The Russian Federation has more than 3.4 million citizens of Uzbekistan and the Russian Federation remains the main foreign labour market for Uzbek citizens. In 2018, Uzbekistan was the leader in terms of the number of migrants in the Russian Federation; between January and September 2018, 1,573,791 people entered Russia for work purposes. [www.eadaily.com/ru/news, 2018].

- Cultural and linguistic community. For many decades the countries have been united by the Russian language, which is a means of inter-ethnic communication. The Russian Cultural Centre is active in Uzbekistan, and there are 676 schools with Russian as the language of instruction, where more than 250,000 students are taught. Every year, 40-45 textbooks and 1.0-1.2 million copies of educational literature are published in Russian, 85 newspapers and 52 magazines are published in Russian. These are periodicals, independent and entertaining publications; their circulation is increasing; Russian-language programs are broadcast on television and radio channels in Uzbekistan; and 16 non-State radio stations currently broadcast 24 hours a day, 7 days a week, in both Uzbek and Russian [Khamdamov Y., 2012].

- General problems, such as the traditional system of education inherited from the Soviet period, related to the need to update the principles of presentation of educational material, the changing role of the teacher in the educational process, the need to introduce innovative technologies into the educational process, the need to equip educational institutions with computers and modern equipment. The unifying factor is also the common problem of «brain drain» and lack of professional staff in both countries.

However, there are still a number of problems that still need to be solved in the education system, especially in secondary and higher education.

First, there is a huge unmet demand for educational services in Uzbekistan. This is due to the limited capital and teaching resources of educational institutions, while the population is growing. According to the Ministry of Higher and Secondary Special Education, in 2018 only 10\% of applicants entered higher education institutions. As a result, approximately 27,000 students left to study in foreign educational institutions.

Secondly, Uzbekistan's main higher education institutions are concentrated in Tashkent, and therefore citizens of remote regions often do not have the opportunity to study there. 
Third, foreign universities have modern courses and programmes that are expensive for our citizens to study in.

The above factors confirm the urgency and task of consolidating the strategic partnership between Russia and the Republic of Uzbekistan under new conditions.

In today's conditions, there is a special need to stimulate educational, research and innovation activities, to create mechanisms for putting its achievements into practice. Accordingly, there is a growing demand for highly qualified personnel and scientific research in all areas of the national economy, which together can not only lead the country out of the current crisis situation, but also contribute to the growth of power and status of the Republic in the world arena. In this regard, the Strategy for the Further Development of the Republic of Uzbekistan for 2017-2021 outlined specific measures for the development of education and science. The document stresses that the main goal is «development of human capital as the main factor determining the level of competitiveness of the country in the world arena and its innovative progress». Russia is the most convenient partner in terms of territorial, cultural and economic proximity, availability of modern educational literature and scientific personnel that is understandable and accessible to the Uzbeks.

The review and analysis of the main current trends, directions and new approaches in the sphere of interaction in education and science as one of the main directions in the volume of cultural and humanitarian relations between the Russian Federation and the Republic of Uzbekistan is the purpose of this article.

In this work, cooperation between Russia and Uzbekistan in the field of education and science is highlighted as a component part of the tasks of comprehensive deepening the strategic partnership between the two countries and the implementation of scientific and educational reforms in Uzbekistan. The article takes a new perspective on the scale, causes and first consequences of such partnership, using previously unused sources, publications and data from the media and international organizations.

The new interrelationships that have emerged in the educational segment of the cultural and humanitarian sphere are studied on the basis of an interdisciplinary approach and comparative analysis, including methods of dialectical, comparative and structural and functional analysis.

\subsection{Literature review}

The topical issues of cooperation between Uzbekistan and the Russian Federation are considered in the works of both Russian and Uzbek social scientists. Conditionally, they can be divided into 2 parts: studies in 2008-2016 and studies from 2017 to the present.

\section{$1^{\text {st }}$ part: $2008-2016$}

The researches in this period concerned the issues of economics, cultural-humanitarian and intergovernmental, innovative cooperation. The main areas of economic cooperation between Russia and Uzbekistan in which innovative approaches to economic development were studied at regional and interuniversity conferences [Grechenkova O.Yu.: 2012, Isokhuzhayeva M.Y.: 2014]. The scientists covered the issues of bilateral economic cooperation and prospects of cooperation in the fuel industry of Uzbekistan and Russia, the current issues of bilateral economic cooperation [Abduvaliev A.A.: 2010, Terent'ev M. A.: 2010, Shadiev F.A.: 2015].

In Talipova N.T.'s works the historical aspects of development were studied [Talipova N.T.: 2016], the scientific analysis of objective trends in the development of the foreign economy of the Republic of Uzbekistan in the aspect of strategic partnership with the Russian Federation was conducted, as well as the high level of interaction and sustainable indicators of economic, cultural and scientific cooperation were studied [Talipova N.T.: 2019]. The main tendencies of development of foreign economic cooperation, a great attention to foreign economic cooperation, liberalization of foreign trade and mechanisms to reduce trade barriers as factors of regional integration, as well as the activities of joint ventures operating in the territory of Uzbekistan were highlighted by 
a number of authors, as a result, identified the main trends and prospects for further cooperation, as well as presented proposals to strengthen cooperation between Russia and Uzbekistan. [Ziyadullaev et al., 2016]. Some authors considered the state and prospects of investment cooperation between Uzbekistan and Russia [Beregovyh T.V., Saifullaev U.M.: 2016], the role of Russia in the development of industrial sectors in Uzbekistan [Shermukhamedov A.T.: 2016], the strategic cooperation of Uzbekistan with Russia in energy and transport sectors.

A number of researchers have carried out in-depth research on the status and parameters of the comprehensive expansion of interstate, intergovernmental and innovation cooperation between Russia and Uzbekistan. [Ionova E.P.: 2009, Rudov G.A.: 2012, Veshkurova A.B., Olennikova O.V.: 2017, Isohujaeva M.Y.: 2019] and many others.

The issues of mutually beneficial cooperation between Russia and Uzbekistan in the field of culturalhumanitarian and interfaith interaction were considered in the works of F.S. Rashidova [Rashidova F.S.: 2012]. The role of international cooperation in professional development of pedagogical staff was also studied by a number of scientists - B.E. Hasanov [Hasanov B.E.: 2010], practical and innovative models of international cooperation in higher education system of Uzbekistan were covered by S.U. Hodzhaniyazov, K.D. Saipova [Hodzhaniyazov S.U.: 2012, Saipova K.D.: 2015].

\section{$2^{\text {nd }}$ part: from 2017 - up to the present time}

During this period, the research mainly touched upon the issues of economic and foreign policy interaction. From 2017 to the present day, there have been a number of studies, most of which relate to economic interaction between Russia and Uzbekistan. Nevertheless, the main trends and prospects for further cooperation, conceptual directions of trade and economic cooperation and deepening of relations between Uzbekistan and Russia in the context of modern foreign policy and foreign economic tensions were identified in the works of a number of scientists [Orozbaeva A.B., Kemelbekov A.A.: 2017, Miagkov V.Yu.: 2018]. By the example of relations between Russia and Uzbekistan the impact of investment cooperation on the state economic management was studied Makhmutkhodjaeva L.S., Talipova N.T. There were considered the issues of development of cultural and humanitarian ties [Makhmutkhodjaeva, L.S., Talipova N.T.: 2019], the analysis of the development of the foundations of military cooperation was carried out in the works published in foreign journals.

Important sources of the investigated problem are the works devoted to the prospects of cooperation between Uzbekistan and Russia in the field of tourism and education [Khaitboyev B.H., Najmiddinov S.N.: 2019].

As we can see, the scientific literature on the history of Uzbek-Russian relations is quite widely represented, often the subject of research by modern scientists, but it should be noted that the direction of cooperation in education and science in the period from 2017 has not yet been studied. Moreover, the analysis of existing literature has shown a practical lack of scientific literature devoted to the analysis of cooperation in science and education, a gap that this work seeks to fill.

\section{Methodology}

\subsection{New stage of strategic partnership between the Republic of Uzbekistan and the Russian Federation}

The strategic significance and political potential of Uzbekistan point to the fact that the state objectively has special responsibility for the Central Asian region, and the optimal way to solve the existing problems in the relations between the states of the region is through interaction between the countries. Located in the heart of Central Asia, Uzbekistan, on the one hand, has rich natural resources, manpower, cultural diversity and a favorable strategic location, which serves as a powerful springboard for the development of the country's 
economy. On the other hand, the country has no direct access to seaports and is far away from many global economic centers. Geo-strategic and trade-economic relations between Russia and Uzbekistan are mainly shaped taking into account a number of critical factors:

First, the historical ties between Uzbekistan and Russia (becoming part of the former Soviet Union).

Secondly, geostrategic - in modern conditions, the development of relations between the Russian Federation and the countries of the Central Asian region is important, because with the collapse of the Soviet Union, the post-Soviet space has acquired an entirely new geopolitical and geostrategic significance.

Third, geographical - Russia and Uzbekistan have a relatively favorable transport and geographical location.

Fourthly, modernization - both countries are implementing reforms aimed at forming market mechanisms of economic management and modernization, rational use of the rich natural and economic potential.

Fifth, Euro-Asian civilization and a secular way of life.

Sixth, ethnocultural - ethnic Russians live in Uzbekistan and occupy a certain place in social and industrial activities [Decree of the President of the Republic of Uzbekistan №UP-4947, 2017].

Seventh, linguistic - for many years Russian has been a means of communication for citizens of both countries, a way of access to world science and literature.

These factors largely determine the national interests of Russia in the development of strategic and trade and economic relations with Uzbekistan.

A compilation of official statements, press materials and the opinions of scholars and specialists made it possible to formulate the following goals and interests of Uzbekistan in cooperation with Russia: ensuring political, economic and social stability on the basis of partnership of states; the right of unimpeded transit through the territory of Russia; the use of Russia's support and influence for military needs, the creation of a buffer zone for protection from various threats coming from the south; the use of Russia's scientific and educational potential in reforming the Soviet Union; and the use of scientific and educational resources for the development of strategic and trade relations with Uzbekistan.

At present, about 200 interstate, intergovernmental and interdepartmental agreements regulating communications in various fields constitute the legal and contractual basis for Russian-Uzbek cooperation. Uzbekistan and Russia are cooperating fruitfully within such international structures as the UN, SCO and CIS.

Although relations with Russia were strategic in nature, they were not elevated to the rank of national priorities until 2017 and were developing unevenly. Only in recent years did stable and sustainable growth emerge.

The changes that have taken place on the political map of the world, related to the issues of geopolitics and globalization have prompted the leadership of the two countries to optimize interaction, which was expressed in the signing of a number of agreements and documents, signed during the Russian-Uzbek negotiations at the highest level, as well as agreements reached within the Forum of Interregional Cooperation «Uzbekistan Russia» in Tashkent (October 19, 2018), as a result of which the leaders signed a large package of documents on large-scale cooperation between two countries.

The advantages of globalization are determined by the economic benefits that are derived from the use of advanced scientific and technological, technological and qualification level of the leading in the relevant areas of foreign countries in other countries. In these cases, the introduction of new solutions takes place in a short time and at relatively low cost. At the same time, globalization contributes to aggravating international competition [Isokhuzhayeva, 2014]. 
It should be concluded that the interstate cooperation between Uzbekistan and Russia is currently witnessing a new stage, in which our countries, in fact, have drawn up a detailed plan of cooperation for many decades ahead.

\section{Results}

\subsection{Cooperation in science}

In modern conditions, Uzbekistan is successfully developing cooperation with the Russian Federation in the field of science through bilateral scientific and practical conferences, seminars, joint scientific projects and educational centers.

On a regular basis, our countries hold bilateral scientific and practical international conferences involving a large number of scientists and teachers from Russia and Uzbekistan on scientific and humanitarian cooperation.

In particular, in October 2017, an international conference entitled «Historical and cultural ties between Russia and Uzbekistan and the prospects for humanitarian cooperation in the modern period» was held at the Lomonosov Tashkent State Pedagogical University. In particular, in October 2017, the international conference "Historical and cultural ties between Russia and Uzbekistan and prospects for humanitarian cooperation in the modern period» was held at the Nizami Tashkent State Pedagogical University, co-organized by Orenburg State University and the Autonomous Nonprofit Organization "Commonwealth of the Peoples of Eurasia» with the support of the Representative Office of Rossotrudnichestvo; in November 2017, the Tashkent branch of the Lomonosov Moscow State University held an international conference on «New horizons of strategic partnership between Uzbekistan and Russia: economy, security, humanitarian dialogue», where heads of ministries and departments of our country, members of the Russian delegation spoke.

Cooperation between sociologists of Uzbekistan and Russia is actively developing; a scientific and practical seminar on "Actual problems of studying public opinion: theory, methods, practice» was held in Tashkent, attended by researchers from the "Izhtimoi fikr» Centre for the Study of Public Opinion of Uzbekistan and the Russian Centre for the Study of Public Opinion, representatives of higher educational institutions, government agencies and the mass media (October 2018). At the end of the seminar, as part of the renewed cooperation agreement, an exhibition entitled "Russia Surprises» is planned to be held on a special project of the Russian Centre for the Study of Public Opinion in Uzbekistan on the basis of the «ljtimoii fikr» Centre, to explore the possibility of implementing such a popular science project for Uzbekistan, and also to hold a special field session of the sociological school of the Russian Centre for the staff of the "ljtimoii fikr» and young researchers from other organizations and higher education institutions of Uzbekistan in the spring of 2019.

Important for scientific cooperation of our countries is the project of radio astronomical observatory on Suffa Plateau, which is carried out by the Academies of Sciences of both countries together with the Centre for Science and Technology under the Cabinet of Ministers of Uzbekistan. In October 2018 the project was implemented by the Academy of Sciences of both countries together with the Centre for Science and Technology under the Cabinet of Ministers of the Republic of Uzbekistan. Presidents of the Academy of Sciences of Uzbekistan B. Yuldashev and the Russian Academy of Sciences Sergeev signed a plan of action and a road map for the establishment of an international research organization "International Radio Organization of the Suffa Observatory», are negotiating an agreement with MSU on the joint operation of the Maidanak Observatory on Mount Maidanak in Kashkadarya, Uzbekistan. Currently, cooperation is being established as part of the creation of a national system of space communications, and Uzbekistan is considering the possibility of joining the joint launch of a satellite with Kazakhstan, which will provide high-speed Internet, telephony and TV and radio broadcasting.

In researching cooperation in the field of science, it is necessary to note the importance of opening the Interdisciplinary Scientific and Educational Center "Lomonosov - Mirzo Ulugbek" at the National University of Uzbekistan named after Mirzo Ulugbek on October 18, 2018. To date, this is the only scientific and educational 
center in Uzbekistan, in the current situation, when ties between Uzbekistan and Russia are so intensively developing - it will greatly help in training graduate students, masters in currently in demand specialties. It is planned that the Lomonosov - Mirzo Ulugbek Scientific and Educational Center should become a venue for educational projects and initiatives, scientific seminars and conferences with involvement of young scientists from universities of both countries. It can be assumed that the activities of this project will be effective and in demand for building new long-term scientific ties between the Mirzo Ulugbek National University of Uzbekistan and the Lomonosov Moscow State University.

Thus, we see that the holding of joint conferences, seminars, organization of educational centers and work on joint scientific projects allow not only to strengthen the historical ties between Russia and Uzbekistan, but also provide an opportunity to reach a new qualitative level of scientific interaction between our countries, to see common ground in concrete scientific research.

\subsection{Cooperation in education}

Cooperation between Russia and Uzbekistan in the field of education includes such directions as projects and programs of «Rossotrudnichestvo» in Uzbekistan, activities of branches of Russian universities, opening of new branches, joint faculties and educational programs, systematic work carried out to popularize the Russian language, as well as programs for training and retraining of secondary school teachers.

For example, every year "Rossotrudnichestvo» implements projects and programs in Uzbekistan aimed at exporting Russian education, promoting international scientific cooperation, attracting foreign nationals to study in Russia, and cooperating with graduates of Russian universities. Every year, the Russian Centre for Science and Culture in Tashkent prepares students for admission to Russian universities and recruits them for courses at the Russian Centre for Science and Culture in Tashkent (September, 2018).

Today Uzbekistan is one of the first CIS countries in terms of the number of students studying in Russian universities, where more than 25 thousand students from Uzbekistan study. There has been an increase in the admission quotas for Uzbek applicants to Russian universities (see Fig. 2).

The activity of branches of Russian universities in Uzbekistan is a great importance for active cooperation between Russia and Uzbekistan in the field of higher education. At present, there are more than ten branches of Russian universities and joint faculties in Uzbekistan. The first branch of the Russian higher education institution in Uzbekistan was the Tashkent branch of the Plekhanov Russian Economics University, established by Order No. 1356 of the Ministry of Education of the Russian Federation dated 28 March 2001. The main activities of the branch are training highly qualified economists with higher education, retraining and advanced training of existing specialists, research and consulting activities in the field of personnel management, labor economics, social protection, etc. The graduates of the branch are awarded a diploma of graduation from the Plekhanov Russian University of Economics, which is a document on higher education in the Republic of Uzbekistan, recognized by specialists of the world's leading universities, certified by the UNESCO Commission and the Bologna Convention. During its existence, the branch has graduated more than 3400 bachelors and masters, which confirms the demand for graduates in the regional labor market. A significant merit of the branch is its staff, more than $70,0 \%$ of the total number of teachers have doctoral and candidate degree. For the development of effective activity of the branch in Tashkent in accordance with the Decree of the President of the Republic of Uzbekistan the Rector of the Republican Economic University named after G.V. Plekhanov Professor V.Grishin was awarded the state award of Uzbekistan - the Order «Dustlik».

The second Russian branch, which opened in Uzbekistan in September 2006, is a branch of the Lomonosov Moscow State University. The total area of the branch is $540 \mathrm{~m}$, it is equipped with distance learning classrooms, a conference hall for 220 people, a training room, a studio, 4 flow and 11 classrooms, 3 language laboratories, the branch has an information and resource center, 6 computer science classrooms, training laboratories. Currently, the Lomonosov Moscow State University branch in Tashkent has two departments - applied 
mathematics and a psychology department; more than 60 invited foreign specialists participate in the educational and scientific process of the branch; it should be noted that Uzbekistan leads in the number of applicants for study at Moscow State University.

On 13 January 2007, the President of Uzbekistan issued a decree on the organization of the activities of the branch of the Gubkin Russian State University of Oil and Gas in Tashkent. The branch is equipped with modern teaching and laboratory equipment, computer and other office equipment, an information and resource center designed to store 100,000 books, more than four thousand books on electronic media, 38 computerized places of access to information resources, educational and methodological literature, electronic copies of textbooks can be used in other technical universities in Tashkent, at the service of students about 100 brochures with scientific articles of those who stood at the origin of the oil and gas industry. Advanced teaching and information technologies and the latest achievements in science and higher education have been introduced into the teaching process at the branch. Teachers in Uzbekistan and Russia provide training, and modern technologies help students to better understand the material they are studying, and allow them to hold teleconferences and tele-seminars. It should be noted that the diploma of I.M. Gubkin Russian State University of Oil and Gas issued to the graduates of the branch is recognized as a higher education document of the University [Nazarov R.R.].

In September 2018, a branch of the Moscow National Research Technological University of Steel and Alloys began operating in Almalyk. At the same time, a joint faculty with the Ural State University of Economics was opened at Tashkent State Economic University.

Speaking about cooperation with Russia, President Mirziyoyev emphasized the role of Russian branches in the development of higher education: "I would like to note the successful activities in Uzbekistan of branches of Lomonosov Moscow State University, Plekhanov Russian University of Economics, Gubkin Russian State University of Oil and Gas, which make a worthy contribution to training highly qualified personnel for our countries. I would like to emphasize that we are interested in further development of ties with Russian higher education institutions and research centers».

The new phase in cooperation between the Russian Federation and the Republic of Uzbekistan in the field of education began in 2018. On 19 October 2018 the Ministers of Higher and Secondary Special Education of Uzbekistan and Science and Higher Education of the Russian Federation signed an agreement between the governments on the establishment and operation of a number of new branches of Russian higher education organizations in Uzbekistan, it was decided that in order to improve the conditions for the functioning of Russian higher education institutions in Uzbekistan, they will be granted tax benefits and preferences, the procedure for their registration will be simplified, and mechanisms of public-private partnership will be introduced. In 2018, agreements were signed to open 6 more branches of Russian universities in Uzbekistan from 2019-2020 academic year:

- between the rectors of the University of World Economy and Diplomacy and the Moscow State Institute of International Relations to establish a branch of MGIMO in Uzbekistan;

- a branch of the National Nuclear Research University, the Moscow Engineering Physics Institute;

- a branch of the Mendeleev Russian Chemical and Technological University; and the Moscow State Institute of International Relations;

- a branch of the National Research University, the Moscow Power Engineering Institute;

- Gerasimov Moscow State Institute of Cinematography;

- a branch of the A. Pushkin State Institute of Russian Language and Russian language centres on the basis of higher education institutions that specialize in Russian language and literature (see Fig. 3. Dynamics of opening branches of Russian higher education institutions in Uzbekistan). 
In 2019, as a result of the contracts signed, several branches were opened in Uzbekistan, such as MISIS, the MIFI Nuclear University, the Moscow State Institute of International Relations (MGIMO), the Russian State University of Physical Culture, Sports, Youth and Tourism and the Mendeleev University of Chemical Technology «MPEI».

The Samarkand branch of the Russian State University of Physical Culture, Sport, Youth and Tourism of the Russian State University of Physical Culture, Sport, Youth and Tourism was established by Presidential Decision No. PP-4311 of 8 May 2019. The purpose of opening branches of Russian universities is further development and improvement of training of highly qualified personnel with higher education, creation of conditions for realization and effective use of potential of gifted youth in social and economic development of the country, expansion of international cooperation in higher education. In addition to the branches of Russian universities, dozens of joint faculties and educational programs will also be opened in Uzbekistan. Representatives of more than 80 Russian universities, as well as heads of relevant ministries and departments took part in the first educational forum «New Personnel for New Economy» held in Tashkent in October 2018. Its result was the signing of about 150 agreements on cooperation between leading higher education institutions of two countries, behind each of which there are "road maps» on creation of branches, joint faculties, scientific and educational programs. The International Education Forum has become a source of new impulses that contribute to improving the quality of training, development and improvement of educational and scientific processes in the system of interaction between potential partner universities, its goal was to significantly strengthen cooperation between our countries in higher education and science, contributing to the deepening of interstate interaction as a whole. As part of the Forum, an important stage of cooperation in the field of education between Russia and Uzbekistan began - a Cooperation Agreement was signed between the Academy of Public Administration under the President of the Republic of Uzbekistan and Lomonosov Moscow State University, agreements were concluded between the Council of Rectors of Higher Education Institutions of Uzbekistan and the Russian Union of Rectors, agreements on the establishment of an interdisciplinary scientific and educational center between the National University of Uzbekistan and Moscow State University, and a number of other agreements were announced. One of the priority languages for Uzbekistan today is Russian, and the Uzbek State University of World Languages is doing a great job to popularize Russian. Interest in Russian has always been strong, but now it is steadily growing. In 2018, the first year of the Russian Philology Department will see more than three hundred students studying, three times more than two years ago. In order to popularize the Russian language and culture as important elements of world civilization and to strengthen mutual understanding between peoples, a year ago the first Russian Language Center was opened at the University with the support of the Representative Office of "Rossotrudnichestvo». Within the framework of the conceptual approach to cooperation, the University of World Languages is actively implementing agreements with leading Russian universities, such as Moscow State Linguistic University, Vladimir State University, Kalmykia State University, Kalmykia State University named after M.V. Lomonosov, Moscow State University of the Russian Federation, Moscow State University of the Russian Federation, Moscow State University of the Russian Academy of Sciences, Moscow State Pedagogical University, Moscow State Pedagogical University, Moscow State University of the Russian Academy of Sciences, Moscow State Pedagogical University, Moscow State Pedagogical University, Moscow State Pedagogical University, Moscow State Pedagogical University, and others. Moscow State Linguistic University, Vladimir State University, Kalmyk State University named after B. Gorodovikov, Pushkin Institute of Russian Language. Within the framework of the International Educational Forum in October 2018 the University of World Languages prepared for signing new agreements on cooperation with the Astrakhan State University, Kurgan State University, Nizhny Novgorod State University, according to the agreement, there will be joint work on conducting joint research projects, lectures, organization of social, cultural and scientific events, etc.. As we can observe, there is a positive dynamics in the partnership between Republic of Uzbekistan and Russian universities: from 2001 to 2019, only 11 branches of Russian universities started their activities in Uzbekistan (Fig. 3), mentioned in Table 1: 
A topical issue for Uzbekistan is the lack of qualified staff for general education schools; Uzbekistan and Russia intend to develop cooperation in training teachers for secondary schools. In this regard, the leadership of the Ministry of Public Education of Uzbekistan held talks with the Russian delegation in September 2018 and discussed the establishment of cooperation in education between Uzbekistan and Russia. Given the current shortage of teachers in Uzbekistan, especially in Russian-speaking schools, it was proposed to establish cooperation with Russian educational institutions for the training and retraining of teachers in Uzbekistan, to cooperate within the Pushkin Institute partnership network, which provides an opportunity to train highly qualified teachers of the Russian language. Within the framework of this cooperation, it was proposed to send young people from Uzbekistan for training in pedagogical areas [Abdurakhmanov K.H., Makhmutkhojaeva L.S., Khakimov N.H., 2019].

Higher education is a fundamental component of human capital; competitive education is directly related to the reform processes in Uzbekistan. In this regard, the main direction is to stimulate research and innovation activities in higher education, which create conditions for the dynamic development of society and improve the quality of the process of training competitive personnel, wide involvement of gifted young people in higher education, strengthening the scientific potential of higher educational and scientific institutions, which is the main factor in the innovative development of the country [Isokhuzhayeva M.Y., 2019]. At the current stage, the development of education in Uzbekistan, its internationalization and the growth of human capital are strategic tasks that directly affect the country's future prosperity and the sustainable growth of the economy, science, culture and other sectors. The internationalization of education is becoming an important factor in the modernization of the country's economy. Foreign internships, dual diploma programs and joint modules not only make it possible to improve the quality of education but should also serve as an important source of attracting new technologies and knowledge into the economy. The basis for joint cooperation should be the development of master's and postgraduate programs, the mutual management of postgraduate students and the possibility of joint publications for scientists from the two countries. Close scientific and educational cooperation with the Russian Federation plays a huge role in this process.

As we can see, the expansion of international cooperation between Uzbekistan and Russia in the field of education and its concretization is the main result of the systematic activities of the countries in this direction and leads to the creation of a single educational, scientific, intellectual and creative space.

\section{Conclusions}

Thus, assessing the current partnership in conditions of formation of innovative culture between Russia and Uzbekistan, we observe its steady growth and come to the following conclusions:

Firstly, education is the main way to unite and realize the possibilities of innovative culture and knowledge society. It is obvious that the main way of solving the problems of maximizing the opportunities of innovative culture and knowledge society lies in the sphere of science and education, which is a significant advantage of countries with strong educational potential.

Secondly, problems and contradictions of modern innovative development of culture are socially determined by objective processes taking place in new conditions of development of global problems and formation of information society.

Third, the development of innovative educational institutions is guided by the system of certain historical educational traditions.

Fourth, the distinctive feature of the new stage of development of innovative culture and knowledge society is the new requirements to partnership in the conditions of innovative culture and knowledge society. The time 
goes by when innovations or knowledge were considered only in narrow spheres of economy, education, etc., out of touch with each other, out of touch with different sectors of civil society, different subjects of activity, including national and international.

Among the expected results can be attributed:

- a new strong impetus given to scientific institutions and individual specialists working on innovative culture in the knowledge society;

- increased and strengthened interministerial, interregional and international relations and cooperation among the above institutions and specialists;

- the establishment of a global network of research and practice on culture of innovation in the knowledge society;

- strengthening the intensity of contacts that can be made in such areas as the involvement of young people in the exact sciences, joint research, student exchanges and joint conferences;

- further development of the presence of Russian educational institutions in Uzbekistan through a system of distance learning, which would improve the level of training of highly qualified personnel and postgraduate education.

Cooperation in science and education between the two countries should be further developed, as the innovative culture within the knowledge society is a strategic resource of the new century.

\section{Bibliographic references}

A branch of the Moscow Energy Institute will appear in Uzbekistan. (2018, 24 October). Retrieved from: https://kun.uz/ru/news/2018/10/24/v-uzbekistane-poavitsa-filial-moskovskogo-energeticeskogo-instituta.

Abdurakhmanov K.H., Makhmutkhojaeva L.S., Khakimov N.H. etc., (2019, 25 March). Higher education as an important factor of sustainable development of the country. Revista ESPACIOS, Vol. 40 (№9), Venezuela. Retrieved from: http://www.revistaespacios.com/a19v40n09/a19v40n09p15.pdf

Abduvaliev A.A. (2010). Innovative and investment aspects of the economic development of Uzbekistan. Journal of Modernization of Economy. Access mode: https://cyberleninka.ru/article/n/innovatsionnoinvestitsionnye-aspekty-ekonomicheskogo-razvitiya-uzbekistana

Beregovyh T.V., Saifullaev U.M. (2016). The state and prospects of investment cooperation between Uzbekistan and Russia. Problems of finance, credit and accounting in the context of economic reform, Volume 1, PNU, Khabarovsk g, pp. 11-14.

Decree of the President of the Republic of Uzbekistan "On strategy of actions for further development of the Republic of Uzbekistan", №UP-4947 07.02.2017 (2017). Retrieved from: http://lex.uz/docs/3107042

Development of cooperation between sociologists of Uzbekistan and Russia. (2018, 24 October). Retrieved from: http://uza.uz/ru/society/razvitie-sotrudnichestva-mezhdu-sotsiologami-uzbekistana-i-r-24-10-2018

Grechenkova O.Y. (2012). Ways of solving the problems of labor migration from Uzbekistan. In the collection: Materials for the VIII international scientific practical conference. pp. 82-83. - Access mode: https://cyberleninka.ru/article/n/pravovoy-mehanizm-gosudarstvennoy-politiki-v-oblasti-zanyatosti-itrudoustroystva 
Hasanov B.E. (2010). International cooperation of uzbekistan in advancing the qualification of pedagogical staff. Science, education, technology. Access mode: https://cyberleninka.ru/article/n/mezhdunarodnoesotrudnichestvo-uzbekistana-v-povyshenii-kvalifikatsii-pedagogicheskih-kadrov

Hodzhaniyazov S.U. (2012). Practical models of international cooperation in the higher education system of Uzbekistan. Teacher of the XXI century. №3, pp. 59-63. - Access mode:

https://cyberleninka.ru/article/n/prakticheskie-modeli-mezhdunarodnogo-sotrudnichestva-v-sistemevysshego-obrazovaniya-uzbekistana

International scientific and humanitarian conference in Tashkent. The Russian Centre for Science and Culture in Tashkent. (2017, 26 October). Retrieved from: http://uzb.rs.gov.ru/\%C2\%A0/news/36664?category_id=15

Ionova E.P. (2009). Anti-crisis policy of Tashkent. Russia and the new states of Eurasia. 2009. No.3.

Isokhuzhayeva M.Y. (2014). The impact of globalization on the world economy. In Collection: Economics and Management: Problems, Trends, Prospects Collection of Materials of the International Scientific and Practical Conference. pp. 56-58. Retrieved from: https://www.elibrary.ru/item.asp?id=23802743

Isokhuzhayeva M.Y. (2019). Features of the use of innovative technologies in educational activities of the Republic of Uzbekistan / Collection: Transformation of higher education system in digital economy - forced necessity or natural process. Proceedings of the International Scientific and Practical Conference. pp. 168175. Retrieved from: https://www.elibrary.ru/item.asp?id=41113446

Khaitboyev B.H., Najmiddinov S.N. (2019). Experience of foreign countries in the formation of digital economy: conclusions and prospects for Uzbekistan. M. №10 (46), p. 11-15.

Khamdamov Y. Journalism of independent Uzbekistan. (2012). KazNU Herald, Almaty. Retrieved from: https://articlekz.com/article/8683

Makhmutkhodjaeva L.S., Talipova N.T. (2018). Cooperation in the field of science and education as an important direction of strategic interaction between the Republic of Uzbekistan and the Russian Federation. Uzbekistan's contemporary history issues. No2, Tashkent. pp. 60-75.

Mirziyoyev S.M. (2017, April 5). Press statements on the results of the Russian-Uzbekistani negotiations Retrieved from: http://www.kremlin.ru/events/president/news/54223

Myagkov V.Yu. and others. (2018). Cross-cultural analysis in the system of international marketing (Arabian East). // Modern problems of management, marketing and entrepreneurship: monograph / Moscow: MGIMO - University, p. 626.

Nazarov R.R. Uzbekistan's cooperation with Russia in cultural and educational sphere. Retrieved from: http://cis.rudn.ru/doc/51

Official website of the Tashkent branch of the Lomonosov Moscow State University in Tashkent city - Retrieved from: https://msu.uz/files/page_files/2018/11/gIrc8zidii92x8kdvqze72g5v.pdf

On the opening of the interdisciplinary scientific and educational center "Lomonosov-Mirzo Ulugbek" in NUUz, (2018, October). Retrieved from: https://fledu.uz/ru/ob-otkrytii-mezhdistsiplinarnogo-nauchnoobrazovatelnogo-tsentra-lomonosov-mirzo-ulugbek-v-natsionalnom-universitete-uzbekistana/

Only the beginning: the leaders of the Russian Federation and Uzbekistan are expanding cooperation. V. Putin and Sh. Mirziyoyev opened the way to strategic partnership. Izvestia uz. (2017, 22 October). Retrieved 
from: https://iz.ru/802845/egor-sozaev-gurev-nataliia-portiakova/tolko-nachalo-lidery-rf-i-uzbekistanarasshiriaiut-sotrudnichestvo

Orozbaeva A. B., Kemelbekov A. A. (2017). International economic regional aspect of cooperation between Russia and Central Asia. Political Science.

Rashidova F.S. (2012). Uzbekistan-Russia: on the path of strengthening mutually beneficial cooperation. Bulletin of Humanitarian Scientific Education, pp. 37-38.

Results of the Russian-Uzbek educational forum. (2018, 19 October). Folk word Retrieved from: http://xs.uz/ru/post/eduforum

Russia was ready to help Uzbekistan to establish a national system of space communications. (2018, October 18). Retrieved from: https://www.gazeta.uz/ru/2018/10/18/roskosmos/

Russian Ministry of Economic Development. (2018). Will there be inflation in 2019. Official data from the Russian Ministry of Economic Development. Retrieved from: https://mukownino.ru/blog/uroven-inflyacziina-2019-god-oficzialnyie-dannyie-minekonomrazvitiya.html

Russian-Uzbek Education Forum - about 130 agreements on cooperation have been signed. (2018, October 19). Retrieved from: https://fledu.uz/ru/rossijsko-uzbekskij-obrazovatelnyj-forum-podpisano-okolo-130soglashenij-o-sotrudnichestve/

Saipova K.D. (2015). The implementation of national policies among the national minorities of Turkestan. / Humanities and Social Sciences in Europe: Achievements and Perspectives. 8 th International symposium 27 th September 2015. - Austria, Vienna,. pp. 26-28

Shadiev F.A. (2015). Russian Federation - Republic of Uzbekistan: cooperation prospects. Topical issues of the innovation economy. No. 9, pp. 201-204. Access mode: https://www.elibrary.ru/item.asp?id=23494744

Shermukhamedov A.T. (2016). The role of Russia in the implementation of innovative projects in the Republic of Uzbekistan. Innovative processes and technologies in the modern world, pp. 176-178.

Speech by Rector of the Uzbek State University of World Languages Rakhimov G.H. at the Russian-Uzbek educational forum "New personnel for new economy", The role of the Russian language in the formation of a new educational space. (2018, 20 October). Retrieved from: https://fledu.uz/ru/rol-russkogo-yazykav-formirovanii-novogo-obrazovatelnogo-prostranstva

State Committee on Statistics of the Republic of Uzbekistan. Inflation in consumer sector of the Republic of Uzbekistan for September 2018. (2018). Retrieved from: https://stat.uz/ru/press-tsentr/novostikomiteta/4789-inflyatsiya-v-potrebitelskom-sektore-respubliki-uzbekistan-za-sentyabr-2018-goda-2

Talipova N.T. (2019) Questions of the dynamics of the inflow of foreign capital into the economy of Uzbekistan. In the journal: Youth and systemic modernization of the country, pp. 63-66.

Talipova N.T. (2016). Russian Federation and Republic of Uzbekistan: regional integration and foreign economic relations. Text of scientific article in the journal "Regional problems of economy transformation". pp. 156159). Retrieved from: https://cyberleninka.ru/article/n/rossiyskaya-federatsiya-i-respublika-uzbekistanregionalnaya-integratsiya-i-vneshneekonomicheskie-svyazi

Terentyev M.A. (2010). Russia and England in Central Asia: at the origins of the Asian geopolitics of Russia (second half of the 19th century). Journal Omsk Scientific Bulletin. Access mode: 
https://cyberleninka.ru/article/n/ma-terentiev-i-ego-trud-rossiya-i-angliya-v-sredney-azii-u-istokovaziatskoy-geopolitiki-rossii-vtoraya- polovina-xix-v

The governments of Uzbekistan and Russia signed 12 documents (2018, 19 October). Retrieved from: https://www.gazeta.uz/ru/2018/10/19/docs/

The official website of the Tashkent branch of the Plekhanov Russian University of Economics. (2019). Retrieved from: www.reu.uz

There are 25,000 students from Uzbekistan studying in Russian universities. (2018, 17 October). Retrieved from: https://kun.uz/ru/news/2018/10/17/v-rossijskih-vuzah-ucatsa-s-tysac-studentov-iz-uzbekistana

Uzbekistan and Russia intend to develop cooperation in training teachers for general education schools. (2018, September). Retrieved from: http://www.uzdaily.uz/articles-id-39565.htm

Uzbekistan continues to be the leader in terms of the number of migrants in Russia. (2018, 14 November). Retrieved from: https://eadaily.com/ru/news/2018/11/14/uzbekistan-prodolzhaet-lidirovat-pokolichestvu-migrantov-v-rossii

UzGUMYa signed a memorandum of understanding (2018, October 19). Retrieved from: https://fledu.uz/ru/ozdjtu-rossiya-federatsiyasining-adegey-davlat-universiteti-bilan-hamkorlik-o-rnatdi/

Veshkurova A.B., Olennikova O.V. (2017). Regional cluster formations as a factor in increasing the competitiveness of the labor force. Scientific notes of the Russian Academy of Entrepreneurship. Publisher: Russian Academy of Entrepreneurship (Moscow), ISSN: 2073-6258. Access mode: https://www.elibrary.ru/item.asp?id=28830551

What documents and agreements have been signed by S.M. Mirziyoev and V.V. Putin. (2018). Retrieved from: https://anhor.uz/news/kakie-dokumenti-i-soglasheniya-podpisali-mirziyoev-i-putin

www.eadaily.com/ru/news. Uzbekistan continues to lead in the number of migrants in Russia., (2018, November 14). Access mode: https://eadaily.com/ru/news/2018/11/14/uzbekistan-prodolzhaet-lidirovatpo-kolichestvu-migrantov-v-rossii

www.izvestia.uz. Only the beginning: the leaders of the Russian Federation and Uzbekistan are expanding cooperation. V. Putin and Sh. Mirziyoyev opened the way to strategic partnership. (2017). Access mode: https://iz.ru/802845/egor-sozaev-gurev-nataliia-portiakova/tolko-nachalo-lidery-rf-i-uzbekistanarasshiriaiut-sotrudnichestvo

Ziyadullaev N.S., Talipova N. (2016). Investment cooperation between the Russian Federation and the Republic of Uzbekistan. Construction economics. No.4 (40), pp. 72-79. Access mode: https://www.elibrary.ru/item.asp?id=26251293 Attribución-NoCommercial 4.0 International

(cc) BY-NC 